\title{
COMPLEMENT INHIBITOR ECULIZUMAB IN ATYPICAL HEMOLYTIC-UREMIC SYNDROME: SINGLE CENTER CASE SERIES
}

Monika Vitkauskaitè ${ }^{1}$, Artūras Vinikovas ${ }^{1}$, Marius Miglinas $^{1}$, Laurynas Rimševičius ${ }^{1}$, Agnè Čerkauskaitè $^{1}$, Ernesta Mačionienè ${ }^{1}$, and Eglè Ašakiené ${ }^{1}$

${ }^{1}$ Vilniaus universitetas Medicinos fakultetas

October 4, 2021

\begin{abstract}
Our case series showed that eculizumab is efficacious and safe in treating atypical hemolytic-uremic syndrome, as well as it has positive effects on quality of life. Further extensive studies are required to develop unified treatment guidelines.
\end{abstract}

\section{Hosted file}

Main_text.docx available at https://authorea.com/users/439437/articles/540379-complementinhibitor-eculizumab-in-atypical-hemolytic-uremic-syndrome-single-center-case-series 